\title{
Men who have sex with men(MSM) and HIV epidemic in China: a web-based study on MSM
}

\author{
Jianmin Xing ${ }^{1 *}$, Konglai Zhang ${ }^{2}$ \\ From $16^{\text {th }}$ International Symposium on HIV and Emerging Infectious Diseases \\ Marseille, France. 24-26 March 2010
}

\section{Background}

To explore MSM population's contribution to HIV epidemic in China through learning AIDS-related knowledge, attitude and behavior among the hidden population-MSM.

\section{Methods}

A web-based cross-sectional study on MSM population, recruiting Men who had sex with men in the previous 3 years in mainland of China through a variety of available ways, such as Internet, mass media etc. and collecting data by online questionnaires and in-depth interview through chat-software QQ or MSN.

\section{Results}

A total of 5710 eligible participants from 30 provinces (municipalities and autonomous regions) except Tibet, and $97.2 \%$ aged between 18 and 44 yrs, 63.3\% thinking that they are likely to be infected by HIV, and $88.7 \%$ knowing counseling hotline on HIV whereas only $8.1 \%$ of them dialed, and 59.8\% knowing at least one site for HIV test whereas of which $40.1 \%$ did, and the number increasing year by year, and in the past 6 months, $90.3 \%$ dating male partners via Internet, and $87.3 \%$ having sex with men and $18.1 \%$ with both men and women and $12.8 \%$ reporting STD-related symptoms. Of 5442 participants, 99.6\% told one could be infected HIV through anal sex with HIV cases and $90.3 \%$ through oral sex, and $95.0 \%$ knew it was more easily infected HIV having unprotected sex with more men. Among 4916 participants who had sex with men, $67.2 \%$ had more than one male partner. The proportions of $100 \%$ condom use when having anal sex with fixed partners, occasional partners, Money-Boys and customers in the past 6 months were $30.0 \%, 42.7 \%, 66.7 \%, 57.9 \%$, respectively;

\footnotetext{
* Correspondence: xjm761002@163.com

${ }^{1}$ Beijing University of Chinese Medicine, Beijing, PR China
}

when having oral sex were $7.0 \%, 8.8 \%, 6.2 \%, 4.4 \%$, respectively. The proportion of $100 \%$ using waterbased lubricants was $45.8 \%$.

\section{Discussion}

Most of MSM are at risk for HIV/STD infection. With increasing HIV prevalence in MSM population, MSM population would make a strong impact on HIV epidemic in China.

\section{Author details}

${ }^{1}$ Beijing University of Chinese Medicine, Beijing, PR China. ${ }^{2}$ Peking Union Medical College, Beijing, PR China.

Published: 11 May 2010

\section{doi:10.1186/1742-4690-7-S1-P103}

Cite this article as: Xing and Zhang: Men who have sex with men(MSM) and HIV epidemic in China: a web-based study on MSM. Retrovirology 2010 7(Suppl 1):P103.

\section{Submit your next manuscript to BioMed Central and take full advantage of: \\ - Convenient online submission \\ - Thorough peer review \\ - No space constraints or color figure charges \\ - Immediate publication on acceptance \\ - Inclusion in PubMed, CAS, Scopus and Google Scholar \\ - Research which is freely available for redistribution

